\title{
e-Tourism beyond COVID-19: a call for transformative research
}

\author{
Ulrike Gretzel $^{1}$ (D) Matthias Fuchs ${ }^{2} \cdot$ Rodolfo Baggio $^{3,4}$ • Wolfram Hoepken ${ }^{5}$. \\ Rob Law $^{6}$ • Julia Neidhardt ${ }^{7}$. Juho Pesonen ${ }^{8} \cdot$ Markus Zanker $^{9} \cdot$ Zheng Xiang $^{10}$
}

Received: 22 May 2020 / Revised: 22 May 2020 / Accepted: 22 May 2020 / Published online: 29 May 2020 (c) Springer-Verlag GmbH Germany, part of Springer Nature 2020

\begin{abstract}
This viewpoint article argues that the impacts of the novel coronavirus COVID-19 call for transformative e-Tourism research. We are at a crossroads where one road takes us to e-Tourism as it was before the crisis, whereas the other holds the potential to transform e-Tourism. To realize this potential, e-Tourism research needs to challenge existing paradigms and critically evaluate its ontological and epistemological foundations. In light of the paramount importance to rethink contemporary science, growth, and technology paradigms, we present six pillars to guide scholars in their efforts to transform e-Tourism through their research, including historicity, reflexivity, equity, transparency, plurality, and creativity. We conclude the paper with a call to the e-Tourism research community to embrace transformative research.
\end{abstract}

Keywords Transformative research · COVID-19 • e-Tourism · Research paradigm • Technology paradigm $\cdot$ Growth paradigm

\section{Introduction}

Since being first reported by the Chinese government to the World Health Organization (WHO) on December 31, 2019 and later declared as a pandemic by the WHO on March 11, 2020 (WHO 2020), the COVID-19 virus, within a short period of only several months, has caused an unprecedented global crisis with enormous impacts on our political, social, and economic systems (Carlsson-Szlezak et al. 2020; Fuchs 2020). As of May 18th, 2020, more than 316,000 deaths have been recorded with more than 4.8 million people infected (see https ://www.worldometers.info/coronavirus/). As its negative effects continue to ripple throughout the world, governments at both regional and national levels have so far issued and implemented policies involving travel bans, community lock-down,

Ulrike Gretzel

gretzel@usc.edu

Extended author information available on the last page of the article 
stay-at-home orders, self- or mandatory-quarantine, and other business-specific restraints to varying degrees (Gössling et al. 2020). As a result, travel and tourism have literally come to a halt, and the economic activities of the airline industry and hospitality sector have been reduced to a small fraction of what they used to be prior to the pandemic. While some economies are gradually reopening, the overall situation remains volatile due to the high contagiousness of the virus and the lack of an immediate treatment or vaccine.

Crises are by no means new to tourism (Blake and Sinclair 2003; Sönmez et al. 1999); however, the impact of COVID-19, at least from an economic point of view, has so far been more devastating than any other crises in recent history (Hall et al. 2020; UNWTO 2020). As such, the crisis has brought forth new questions of how the tourism industry can respond to and recover from this crisis and, ultimately, how travel and tourism will evolve as a socio-economic activity in our society. Finding solutions and answers to these questions is becoming an increasingly important challenge for stakeholders of tourism including the research communities (Gössling et al. 2020; Hall et al. 2020; Higgins-Desbiolles 2020; Jamal and Budke 2020). More importantly, technology plays a central role in all of this.

Ever since the introduction of the Internet to business, information technology (IT) has been an important enabler, catalyst and, in some cases, disruptor for travel and tourism (Werthner and Klein 1999). This is particularly true in today's world in that IT has been woven into every fabric of travel and tourism involving essentially every facet of the travel process, every stakeholder of tourism, and every subdomain of the industry (Benckendorff et al. 2019; Werthner et al. 2015; Xiang 2018). In light of this pandemic, there are early signs that IT has been widely used, adapted and developed to address some of the pressing problems in our daily life, including work, travel, leisure, business as well as governance. Technology has become a major factor in building resilience in tourism (Hall et al. 2017; UNWTO 2020). On the one hand, IT appears to be highly effective and, in many ways, even essential in confronting these pandemic-related problems (e.g., traveler screening, case and contact tracking, online education, and entertainment during lockdown, to name just a few). On the other hand, there are a range of broader issues and concerns resulting from society's reaction to the crisis such as the new digital divide, vulnerability, privacy, misinformation and ethics of using technology, which would have profound and long-term effects across all layers of e-Tourism (Werthner et al. 2015).

Over the last three decades, e-Tourism, as a field of scientific inquiry, has evolved into a substantial body of knowledge with the focus of theory and information technology development aligned with core problems in tourism (Xiang et al. 2021). The profundity and complexity of the impact of COVID-19 require both a short-term reaction and a long-term readiness in order to understand some of its far-reaching effects at the fundamental level. As the intersection between IT and tourism, the field of e-Tourism must now grapple with the two "fronts" of a fast-changing new reality and tremendous prospects for long-term change. As e-Tourism researchers, we find this new reality provides both enormous challenges and exciting opportunities from the perspectives of scientific inquiry and technological innovation. e-Tourism research must now elevate itself to be ready to ask, and prepare to find answers 
to, some critical and significant questions regarding the role of IT in contributing to a better future of tourism and society.

As such, as the editorial team of the Journal, we strongly believe COVID-19 presents an opportunity and also an obligation for us to critically reflect on the field of e-Tourism and, as a result, to offer an outlook for a "transformative" research agenda for e-Tourism research. We develop this call for transformative research based upon a careful and critical assessment of the basic assumptions and value propositions of the existing literature in relation to the broader conversations about the future of tourism and the role of IT in society. Even though the future is uncertain, it is our responsibility to think about the challenges, opportunities, threats and possibilities that exist in the future that can be shaped by e-Tourism research in an impactful way. We believe a paradigm shift is much needed at this watershed moment, and we hope this essay will be of keen interest to the communities surrounding this journal and will help advance e-Tourism research as a whole. To achieve this aim, the paper reviews e-Tourism as a field of study, challenges the paradigms through which it is predominantly shaped, and then suggests six pillars on which to build transformative e-Tourism research.

\section{2 e-Tourism as a field of study}

Neidhardt and Werthner (2018: 1) define the field of e-Tourism as encompassing the "analysis, design, implementation and application of IT/e-commerce solutions in the travel and tourism industry, as well as the analysis (of the impact) of the respective technical/economic processes and market structures". This definition describes the existing research streams within the field, and especially within the Information Technology \& Tourism journal, very well (Buhalis and Law 2008; Wang et al. 2010). First, the notion of IT as a "solution" represents a particular instrumental view of technology as a tool that serves businesses. Second, it stresses micro- and mesolevel perspectives while ignoring macro-level questions regarding the systems and governance approaches that promote, facilitate and regulate specific kinds of technologies. This has already been criticized by Werthner et al. (2015), who emphasize the need to study e-Tourism across all five identified layers, from individuals to government/policy issues, such as ethics and sustainability. Third, this definition of e-Tourism highlights that e-Tourism research so far has been firmly rooted in a conventional rather than a post-digital, humanist paradigm. Individuals are defined and studied as consumers, users, or data sources rather than affective human beings embedded and embodied in physical and virtual communities and places. Like the businesses that provide and use technologies, they are typically conceptualized as beneficiaries of technological "solutions" and therefore willing to be participants in e-Tourism. Technology as such is seen as a given or something that should be improved rather than questioned.

e-Tourism as a subject of scientific inquiry is a dynamic field that has penetrated mainstream tourism research and is continuing to attract the attention of computer science and engineering scholars in search of application areas. However, recent review papers confirm that while the specific technologies studied constantly evolve, 
the research streams within e-Tourism have remained remarkably stable (Law et al. 2019; Navío-Marco et al. 2018; Touray, 2020; Yuan et al. 2019). What can be seen over the course of e-Tourism research development is the emergence of focus areas and research-activity clusters that correspond to technological advances, like Web 2.0, big data, virtual reality and smart technologies (Buhalis 2019). It is expected that COVID-19 related technology development and implementation will spur similar bursts in e-Tourism research.

In many ways, e-Tourism research has not necessarily been affected by the crisis. While physical tourism has come to a stand-still, past and potential tourists have been busy ruminating about past trips on social media by sharing vacation memories and/or dreaming about future vacations on destination or travel agency websites. Museums have opened virtual doors to their exhibitions and bored wannabe tourists stuck in quarantine are flocking to these and other virtual experiences. Disappointed tourists stranded on trips or at home have been using websites and mobile apps to cancel the trips and make complaints. Residents discuss in forums whether they are delighted or devastated about the disappearance of tourists from their communities and images of the positive effects on nature of the sudden disappearance of tourists from a hotspot like Venice went viral. Airbnb hosts now offer virtual experiences, social media travel influencers continue to produce contents for their audiences, and tourism providers use a multitude of online channels to maintain customer relationships and reassure future tourists. At the same time, tourism providers and their trade associations are engaging in online activism to reveal their dependence on global online platforms. These intensified or new technology use scenarios create a plentitude of data for e-Tourism research.

Simultaneously, the need for technological solutions has been heightened, encouraging the formative side of e-Tourism research to think about, and get ready for, new designs and applications. Specifically, the crisis demands technologies that can facilitate tracking and monitoring of tourists. It requires solutions that can enable the low-touch economy and controlled access scenarios necessary for physical tourism to restart. The crisis further incites thinking about scalability, dynamic systems and real-time information to accommodate rapid changes in demand and supply in anticipation of differential effects of the crisis across the globe and the likelihood of future lock-downs. e-Tourism research should find creative business intelligence solutions for destinations and tourism providers to better forecast markets, simulate scenarios and understand risks. Technologies are also needed to encourage smart business networks and strategic partnerships/information exchanges with regulatory agencies. Further, post COVID-19 technology has to accommodate shifts in consumer behavior (e.g. risk perceptions, last-minute booking, desires for advance reservations in new contexts such as museums, need for highly personalized packages) and likely changes in the interaction modus (e.g. from physical touch to voice or from input to automated detection).

There is no danger of e-Tourism running out of data or application scenarios. Consequently, e-Tourism research could continue as usual, adapting its theories, methodologies, data and design efforts to new business/government requirements and travel realities. However, COVID-19 prompts us to rethink the ontology and epistemology of e-Tourism research. We believe that, in order for e-Tourism 
research to contribute to knowledge creation that truly benefits the future of tourism and society, fundamental assumptions about technology need to be challenged and e-Tourism as a field of scientific inquiry needs to change.

\section{Paradigms challenged: rethinking science, growth, technology in response to COVID-19}

In this section, we reflect upon the opportunity the crisis provides for the transformation of e-Tourism research. Beyond the immediate health crisis, COVID-19 is essentially a crisis of economized societies rooted in the growth-paradigm (Ötsch 2020). In fact, governments worldwide reacted to the crisis based on prognosed GDP shortfalls and steep increases in unemployment with "rescue packages" and "shock therapies" on an unprecedented scale. At the same time, economists downplay the pandemic as a purely natural event that has originated outside of the economic system (i.e., an exogenous shock) and, thus, has nothing to do with economic structures (Nowlin 2017). Further, technology continues to be seen as independent from natural, social and economic systems and, rather, as something that can be used to solve specific problems associated with the crisis without considering larger societal consequences. Last but not least, science is perceived as a means to achieve the medical and technological progress needed to overcome the crisis and to resume previously charted economic growth trajectories. By referring to Brodbeck (2014, 2019), we criticize ontological and epistemological foundations that underpin the current science, technology and growth paradigms.

\subsection{The science paradigm}

Historically, sciences are characterized by three assumptions: all phenomena are reducible to their own physically explainable foundations. As a necessary precondition, an independent researcher subject is capable of observing phenomena as factual objects. Finally, mathematics is considered the ideal methodological, logical and argumentative foundation to conduct "value-free" science. However, like all languages, mathematics, but also theories and facts, have shown to be aspects of the same social world and, thus, cannot be considered as separable entities (Gödel 1930; Putnam 2004). Indeed, theories and their ontological correspondence in reality are socially construed phenomena with perceived specific relevance and meaning (Brodbeck 2019). Scientists in general, but also researchers in e-Tourism, usually reflect too little on the "values" on which theories are based and how they are matched with data, i.e. the social practice of science.

Kuhn's (1962) seminal work 'The structure of scientific revolutions' describes paradigm shifts as breaking-points driven by the social, psychological and ethical nature of sciences. A crisis like COVID-19 has the potential to challenge current paradigms because it rapidly changes conditions and allows "thinking about the unthinkable". This is what Kuhn referred to as the "revolutionary" aspect of paradigm shifts and what Popper (1974) termed the "essential incompleteness of all 
sciences". Particularly in times of crises, sciences are showing their paradoxes and point to the fact that not only their fundamental notions and theories, but also objectified facts and artifacts, such as experiments and technologies, are rooted in the social sphere (Latour 1987). It is impossible to separate theories from societal processes and to develop, discover and approve theories in an illusory separated world of scientific thinking (Brodbeck 2019). Therefore, a scientific paradigm shift needs to be accompanied especially by a shift in the way we think about "values" and "facts" in relation to the economic and technological foundations of society (Latour 2000)_and of tourism in particular.

\subsection{The growth paradigm}

As a "calculative form of thinking", the nature of money reproduces an empty abstract unit and, worse, executes an automatism of the more as the form of money follows the infinite series of numbers- "the archetype of abstract growth" (Brodbeck 2019, 12). Being an empty abstract measuring unit itself, money needs to be related to objectivized and measured things so as to receive their price. This task of objectivization is exactly what modern sciences are primarily specialized in. However, as a consequence, production processes, but also social acts of exchange, technological processes and even skills and the arts, stop being social processes initiated by humans, and rather become "equations" of production functions (Brodbeck 2011). In fact, 'an ontic social act is ontologically redefined through a mathematical form' (Brodbeck 2019, 16). Therefore, qualitative distinctions appear as numeric identities, i.e. become quantitative differences - or disappear. The uniqueness and diversity of social acts of exchange is transformed into "identical" monetary values (Brodbeck 2019). Moreover, monetary thinking enforces the abstract perspective, i.e. things and humans become comparable but empty units. Economic actors do not appear as humans, but as objectivized "rational" decision making machines maximizing their utility or profit.

However, the reference to such a misleading ontology leads to the paradox that economics cannot be considered an empirically exact science, exactly because "free" humans do not behave like mechanical objects of classical physics. Despite the empirical failure of economics, its successful global application and propagation show that it is, first and foremost, not a "value-free" exact science, but rather an "implicit ethic" (Brodbeck 2014, 8). Although economic theory is not capable of explaining economic agents' behavior empirically, its political function seems to influence and "program" human action through the prescription of what is considered economically "rational" (Brodbeck 2014; Ghoshal 2005). While represented through a system of factual statements, economic theories should be uncovered as "implicit ethics" guided by the thought model of calculative thinking and the ontological assumptions of modern science: physicalism, empiricism and mathematization (Allen 2003; Brodbeck 2019). Despite emergent questioning of the growth paradigm for tourism already before the crisis (Dodds and Butler 2019; HigginsDesbiolles et al. 2019; Saarinen 2018), much of the current discourse around tourism during and after the pandemic is colored by the notion that tourism as a 
"demand-driven" economic activity needs to be "stimulated" so that it can "grow" again. Both science and technology are means to serving this end, rather than as transformative forces.

\subsection{The technology paradigm}

Growth ideology is not only the result of the economic imperative, but also of technology (Illich 1992; Rendall 2015; Samerski 2018). Technology is best understood as the relation of humans to their instruments (Illich 1992). In turn, tools and instruments are defined as means with which humans try to realize their goals, from simple knives to complex technological systems and socio-technical institutions, like factories and universities (Illich 1975). In fact, it is important, not to understand technology as an inevitable product of a determinist technological evolution, but rather as a "historically and culturally shaped meaning relation of man to his tools" (Samerski 2018, 1639). However, the continuous equipping of human with productive tools inverts the relation between people and their instruments, i.e., as machines force people to behave like machines, means turn to ends (Illich 1975).

While today's techno-genic institutions form a technological system that colonizes our imagination, reshapes not only our activities, but also our self-perception and social relations, it is crucial to distinguish between two types of tools (Cayley 2005; Illich 1975). "Convivial" tools are fostering the natural ability of their users to act autonomously and mindfully, thus, the tools are modified by, and adapted to, their users. By contrast, "manipulative" tools reduce man to a programmed machine operator, a client whose heteronomous behavior is unconsciously commanded to adapt (Samerski 2018). In fact, convivial tools are easy to use, thus requiring just learning by doing. However, as usage demands a programming of the user or societal structures and technocratic elites make tools indispensable or obligatory, their use is manipulative and out of democratic control. Convivial tools serve the purpose of the user and not vice versa, thus, "allow the expression of personal and societal meaning" (Samerski 2018, 1640). Indeed, we should ask whether, e.g. smartphones, whose role in travel has been highlighted in recent e-Tourism literature, are actually means for the realization of humans' well-being, despite all the 'user-friendly' designs. They not only pre-program desires and habits, but also affect the sense of the self to a degree that users might become addicted to their devices. Countless examples of such manipulative tools have been cited and discussed in recent critiques of those technologies that aim to persuade, surveille, and even "hijack" people's mind (Harris 2016; Tufekci 2014).

Transformative technologies should limit manipulation and comprise all the powerful tools for democratic engagement, participation, transparency, deliberation and political action, as digital commons, open source technologies and open access technologies impressively show (Kallis 2011; Samerski 2018). In addition, publicly shared information is essentially a public good. Whenever new information emerges, due to its socio-historical character, it incorporates the whole societal history of information, thus, should belong to no one in particular. However, in global capitalism, information becomes a resource that favors capital accumulation, and is, 
therefore, treated as a commodity and ever more controlled by powerful corporations (Fuchs 2009). To sum up, "manipulative" tools embedded into broader paradigms of calculative thinking are programming the behavior of humans and, thus, restrict the freedom inherent to a convivial society. By contrast, "convivial" technologies convert current efficiency-focused economies of scarce means towards sufficiency-focused ecologies of desirable social goals (Dierksmeier and Pirson 2010; Samerski 2018).

The COVID-19 crisis has put e-Tourism research at a crossroads. One path leads us to focus on research that subscribes to existing scientific paradigms, conventional notions of technology and growth-driven thinking and, thus, supports bringing back tourism as we knew it. The other path takes a critical stance at what was before and how things were done and helps envision a better future. The latter path requires "transformative" research.

\section{Transformative e-Tourism research}

By transformative e-Tourism research we mean research that makes underlying value systems, institutional logics, scientific paradigms and particular notions of technology visible and therefore transformable. Transformative e-Tourism research encompasses research that critically analyzes and explicitly questions the designs, resulting affordances and likely consequences of technologies and presents alternatives. Further, transformative e-Tourism research transcends immediate industry needs and actively shapes e-Tourism futures. We propose that the following six pillars, namely historicity, reflexivity, transparency, equity, plurality and creativity, are especially important for guiding transformative e-Tourism research:

\subsection{Historicity}

There is a real danger that the COVID-19 crisis will prompt e-Tourism researchers to overly focus on new realities and ignore theory and practice established before the pandemic. By historicity we therefore mean acknowledging historical origins and development of theories and technologies over time and in close relationship with the evolution of social and political ideologies and institutions. Conceptualizing the crisis as a clean break in relation to e-Tourism and consequent dismissal of past research will only heighten the replication crisis in science, which did not receive enough attention in e-Tourism, even before COVID-19.

In particular, e-Tourism research is called to critically discuss and evaluate relevant past studies. This should lead to extracting possible common frameworks needed to assess how the modifications due to the technological solutions that will probably emerge in response to the present crisis will restructure the domain. The aim is to better understand the impacts of technologies at individual, social, economic and political levels, with an obvious focus on the tourism and hospitality domain, but also to consider other domains to avoid possible, and dangerous selfreferentiality (DeSanctis and Poole 1994). 


\subsection{Reflexivity}

The term is used with many variations and meanings (D'Cruz et al. 2007; Widmer et al. 2009). These variations and meanings have, however, all in common a call for a critical evaluation of, and reflection on, the research in a certain domain and awareness of the factors that influence knowledge creation. In essence, reflexive research problematizes knowledge, specifically its relationship to power and its embeddedness in social institutions. Whether referred to as a researcher's individual history/positionality or to a team's attitude, reflexivity is about acknowledging and scrutinizing the tacit knowledge that results from different approaches and outcomes that emerge from the literature and the practice.

Reflexive e-Tourism research explores the ways in which individual researchers, culture, social conditions and structures shape the design and use of technology, and how technology in turn influences cultural and social settings. It is also important to consider the structure of the "institutions" and industrial entities of e-Tourism and their relationship to other institutions as well as their influence on the construction of knowledge in this domain. This "sociology-of-technology" approach (Sassen 2002) also argues for a higher sensitivity to social and cultural differences (Lynch 2008).

A reflexive approach is important to provide e-Tourism research with rigorous theoretical frameworks. It is a prerequisite for implementing meaningful and effective applications and for building architectures that aim at regaining control and independence from frameworks defined or imposed by the dominant technological powerhouses. Reflexivity is also a critical step towards transparency.

\subsection{Transparency}

By transparency we mean revealing of implicit values. Modern science has replaced value-based argumentation with calculative forms of thinking. However, the history of science has shown that eliminating value-based ontologies is impossible. Thus, by questioning the utilitarian and instrumental nature of the current scientific mainstream, transformative e-Tourism research should acknowledge that science cannot be value-free. Both rigor and relevance of e-Tourism research have to be scrutinized from this perspective. Indeed, for rebuilding tourism in the post COVID-19 era, ontological and ethical aspects related to e-Tourism phenomena should be debated more strongly.

When making implicit values explicit, transformative e-Tourism research is critical not only because of devoting its attention to socially problematic aspects, but also by being aware that "scientifically" developed concepts and technologies always refer to certain values that are promoted and strengthened if these technologies will later be applied in society. A particularly critical stance is needed against the utopian welfare and salvation promises of artificial intelligence (AI), especially because of its incapacity to make its knowledge and value structures explicit. This stance is essential because the "learning" of AI does not take place adjacently to the external human and 
non-human world; rather, the learning process is intrinsically tied to it. Transformative e-Tourism research should not accept a world where AI is guiding human patterns of speaking and action as constitutive forces of an increasingly artificial sphere. Consequently, transparency is particularly important in prominent e-Tourism domains such as big data analytics or recommender systems design and evaluation.

\subsection{Equity}

Equity means assessing how research impacts different groups in society. In the wake of COVID-19, the equity of the impacts of e-Tourism research needs to be thoroughly considered. Social equity of the research refers to how the social impacts are distributed regarding costs and benefits and whether this distribution is considered fair and appropriate (Behbahani et al. 2019). We now have the tools to assess and evaluate research both as an academic output as well as based on its effects on society (Hinrichs-Krapels and Grant 2016).

An emphasis on equity requires e-Tourism researchers to embrace diversity and discuss the meaning and outcomes of the research from a broader perspective. For example, gender issues in $\mathrm{AI}$ and robotics design are becoming a pressing concern (Pritchard 2018). With COVID-19, we are seeing an increasing interest in automation and robotics in tourism and hospitality, but the equity of these choices are not thoroughly analyzed. Academic research should aim to develop new tools to rapidly assess the equity of e-Tourism innovations, and equity perspectives should be incorporated in e-Tourism research and design. It is also time to acknowledge the destructive side of e-Tourism research and innovations (Adner and Kapoor 2016; Fuchs et al. 2020). COVID-19 seems to drive faster innovation adoption and we need to reflect upon how this affects different groups in society.

Equity can be achieved by embracing participative society initiatives such as citizen science, enabling voluntary participation in research (Xiang and Fesenmaier 2017). Such opportunities are currently missing from e-Tourism research. Most research in the world is done by universities located in Europe, North America, Australia/New Zealand and East Asia. As research in science and social sciences is increasingly seen as a source of national prosperity (Meo et al. 2013), many countries without their own research infrastructure are under-represented in tourism research (Shen et al. 2018). Equity is built globally, and e-Tourism research should be able to help those most in need, including e-Tourism researchers with limited resources. Open e-Tourism initiatives could provide one pathway towards equity by democratizing data and processes. Participatory software development, for example AI algorithms developed using open source initiatives, allows the wider community to utilize technology and increases the potential to understand the effects of specific technologies on different groups in society.

\subsection{Plurality}

e-Tourism research that embraces more than one worldview and a diversity of approaches will significantly enrich options available for transformation in a 
post-COVID-19 world. E-Tourism research should not conform to a "mainstream" research agenda by narrowly defining itself as a sub-discipline of tourism or information systems. It is applied; it focuses on a variety of contexts surrounding the activities of travel and tourism; and, as such, it is problem-driven (Werthner et al. 2015). However, the problems it tackles emerge from a multitude of areas. It is obvious that today's scientific inquiry fundamentally requires multidisciplinary, interdisciplinary, transdisciplinary, and sometimes even anti-disciplinary perspectives; and, this is particularly true in e-Tourism which is situated, by definition, at the intersection between IT and tourism as well as other increasingly important fields such as data science and digital sociology. As such, e-Tourism research should expand its ontology to enable "outside the box" thinking, and should ask more niche and critical questions that can help the field create new meanings. There are early signs of this movement in some of the recent publications in this journal on topics related to digital nomads and wellbeing in travel, which are relevant to understand emerging mobile life styles and consequences of using technology in travel within the new contexts of COVID-19 (Cook 2020; Mancinelli 2020).

COVID-19 also creates a surge in scientific research, with developments in medicine, technology and data analytics generating an unprecedentedly large amount of literature at an incredibly fast pace (Brainard 2020). Because of this (and the complexity of the new reality), it is much needed for e-Tourism to engage with other scientific fields with urgency, in both an ontological and an epistemological sense. Researchers must come out from their own silos to build bridges that lead to fruitful collaboration. e-Tourism research should not focus only on academic exercises; instead, it should also aim at developing innovative solutions to real world problems, such as enabling policy making around issues like societal well-being and sustainability in a prescriptive way. For example, we should encourage a bottomup approach to technology development that focuses on creating alternatives to a purely growth-driven philosophy that assumes the more, the better. While applied, e-Tourism research should aim to improve its scientific rigor in developing conceptual and theoretical frameworks that articulate both emerging needs and emerging solutions. However, this does not mean neglecting theoretical grounding; instead, we should encourage applying theories in meaningful contexts and continuing testing and retesting them in order to establish their intellectual merit.

\subsection{Creativity}

Major interruptions to global tourism due to COVID-19 incite a refocusing to the core and fundamental matters in many domains, including science. Mounting critiques proclaim that science in general is very good at micro-innovations but lacks vision and ambition. Even worse, reality checks analyzing the progress made in different IT fields have reached conclusions that improvements over time are marginal at best. For instance, when surveying well-cited recent deep learning techniques in recommender system development, Dacrema et al. (2019) showed that many of them cannot be reproduced and even those that could were outperformed by comparably 
simple heuristic methods. Similar observations were made by Musgrave et al. (2020) who identified serious flaws in experimental setups and evaluation procedures.

This lack of creativity, originality and vision is also not unknown in e-Tourism research, a field that often deliberately self-restricts by primarily focusing on the analysis of existing IT solutions and their adoption and acceptance in tourism. These IT solutions have, however, been largely developed outside the e-Tourism community, and even worse, the e-Tourism research community has no or only limited influence on their conceptualization and design (such as, for instance, social media platforms like TripAdvisor). That said, already Hevner et al. (2004) postulate for design science research in information systems, thus the simultaneous pursuit of rigor and relevance is as timely as ever. Science should not only limit itself to rigorously re-applying widely adopted theories such as the Technology Acceptance Model (Lee et al. 2003; Pourfakhimi et al. 2018), but should also aim at creating novel and original technical artefacts and frameworks with high practical relevance or high scientific impact. Creative e-Tourism research goes beyond linear extrapolation from past developments and focuses on deliberately identifying and breaking existing boundaries.

\section{Closing remarks}

The preeminent American biologist and Pulitzer Prize winner E. O. Wilson once said: "The real problem of humanity is the following: We have Paleolithic emotions, medieval institutions and godlike technology." The COVID-19 crisis has revealed the problematic nature of this situation to a great extent-from selfish panic buying of toilet paper to nations and corporations racing to re-establish the status quo, to an almost religious belief in technology as the ultimate savior. Indeed, much of the COVID-19 recovery efforts in tourism now foresee IT to be the indispensable conditio-sine-qua-non: without IT no tourism during and post-COVID-19. In many ways, this has heightened the need to better understand but also challenge, responsibly manage, and proactively create IT as both a short-term response and a long-term means for the renewal of e-Tourism.

We believe IT holds the key to understand the new pandemic-related conditions in relation to how we manage travel along with our everyday life and how we envision a better future for e-Tourism as a phenomenon and a field of inquiry. As such, in this essay we critique and question the ontology and epistemology of existing e-Tourism research, which is deeply rooted in classical assumptions about science, growth and technology and in the "medieval institutions" that shape it. We envision transformative e-Tourism research as being critical of these assumptions but also constructive by building the necessary foundations for change. Specifically, we call for e-Tourism research that is:

1. mindful of the past and the value of continuity (historicity);

2. aware of the factors that influence knowledge creation (reflexivity);

3. explicit about its values (transparency); 
4. sensitive to differential opportunities to participate in research and varying impacts of its findings (equity);

5. open to diversity in topics and approaches (plurality); and

6. willing to break boundaries and be prescriptive (creativity).

The six transformative e-Tourism research pillars are, obviously, by no means all-encompassing and should not be treated as a requirement for every research project e-Tourism researchers engage in. These pillars are intended, rather, as general views that should guide future e-Tourism research as a whole to ask deeper, more impactful, and more critical questions. In addition, some of the views are not mutually exclusive because they share some even higher-level threads that are eventually connected to our fundamental value systems as a society and a civilization, which are also constantly evolving as we continue to battle this and potential future crises. Nonetheless, it is expected that this essay serves as an intellectual 'steppingstone' that supports the communities surrounding this journal, and beyond, to truly elevate e-Tourism research through rigor, relevancy, creativity, and, ultimately, more significant, diverse and equitable contributions to society.

Funding No funding was received for the preparation of this manuscript.

\section{Compliance with ethical standards}

Conflict of interest The authors declare that they have no conflict of interest.

Availability of data and material (data transparency) Not applicable.

Code availability (software application or custom code) Not applicable.

\section{References}

Adner R, Kapoor R (2016) Innovation ecosystems and the pace of substitution: re-examining technology S-curves. Strateg Manag J 37(4):625-648

Allen S (2003) Towards a non-Aristotelian epistemology of science: a review of general semantics. ETC Rev Gener Semant 60(3):228-240

Behbahani H, Nazari S, Kang MJ, Litman T (2019) A conceptual framework to formulate transportation network design problem considering social equity criteria. Transport Res Part A Policy Pract 125:171-183

Benckendorff PJ, Xiang Z, Sheldon PJ (2019) Tourism information technology, 3rd edn. CABI, Boston

Blake A, Sinclair MT (2003) Tourism crisis management: US response to September 11. Ann Tour Res 30(4):813-832

Brainard J (2020) Scientists are drowning in COVID-19 papers. Can new tools keep them afloat? https:// www.sciencemag.org/news/2020/05/scientists-are-drowning-covid-19-papers-can-new-tools-keepthem-afloat. Accessed 21 May 2020

Brodbeck KH (2011) Money: the global power of an illusion. A Buddhist perspective. In: Fay ISCA, Bruckner M (eds) Buddhism as a stronghold of free thinking-Social, ethical and philosophical dimensions of Buddhism. Ubuntu, Ulm 
Brodbeck KH (2014) Verborgene metaphysische Voraussetzungen in der zeitgenössischen Wirtschaftslehre. Working Paper Series, No. Ök-02, Cusanus Hochschule, Institut für Ökonomie und Institut für Philosophie, Bernkastel-Kues

Brodbeck KH (2019) Die Illusion der Identität und die Krise der Wissenschaften, Working Paper Serie der Institute für Ökonomie und für Philosophie, Cusanus Hochschule. No. 47, 032019

Buhalis D (2019) Technology in tourism-from information communication technologies to eTourism and smart tourism towards ambient intelligence tourism: a perspective article. Tour Rev 75(1):267-272

Buhalis D, Law R (2008) Progress in information technology and tourism management: 20 years on and 10 years after the Internet-the state of eTourism research. Tour Manag 29(4):609-623

Carlsson-Szlezak P, Reeves M, Swartz P (2020) What coronavirus could mean for the global economy? https://hbr.org/2020/03/what-coronavirus-could-mean-for-the-global-economy. Accessed 21 May 2020

Cayley D (2005) The rivers north to the future. The testament of Ivan Illich. House of Anansi Press, Toronto

Cook D (2020) The freedom trap: digital nomads and the use of disciplining practices to manage work/ leisure boundaries. Inf Technol Tour. https://doi.org/10.1007/s40558-020-00172-4

Dacrema MF, Cremonesi, Jannach D (2019) Are we really making much progress? A worrying analysis of recent neural recommendation approaches. In: Paper presented in the 13th ACM conference on recommender systems, 16-20 September 2019, Copenhagen, Denmark

D'Cruz H, Gillingham P, Melendez S (2007) Reflexivity, its meanings and relevance for social work: a critical review of the literature. Br J Soc Work 37(1):73-90

DeSanctis G, Poole MS (1994) Capturing the complexity in advanced technology use: adaptive structuration theory. Organ Sci 5(2):121-147

Dierksmeier C, Pirson M (2010) The modern corporation and the idea of freedom. Philos Manag 9(3):5-25

Dodds R, Butler R (2019) Overtourism: issues, realities and solutions, vol 1. De Gruyter, Berlin

Fuchs C (2009) Information and communication technologies and society. A contribution to the critique of the political economy of the Internet. Eur J Commun 24(1):69-87

Fuchs C (2020) Everyday life and everyday communication in coronavirus capitalism. TripleC: communication, capitalism \& critique. J Glob Sustain Inf Soc 18(1):375-399

Fuchs M, Fossgard K, Stensland S, Chekalina T (2020) Creativity and innovation in nature-based tourism: a critical reflection and empirical assessment. In: Fredman P, Haukeland JV (eds) New frontiers in nature-based tourism: principles and practice. Routledge, London (in print)

Ghoshal S (2005) Bad management theories are destroying good management practices. Acad Manag Learn Educ 4(1):75-91

Gödel K (1930) Über die Vollständigkeit der Axiome des logischen Funktionenkalküls. Monatshefte für Mathematik und Physik 37(2):349-360

Gössling S, Scott D, Hall CM (2020) Pandemics, tourism and global change: a rapid assessment of COVID-19. J Sustain Tour. https://doi.org/10.1080/09669582.2020.1758708

Hall CM, Prayag G, Amore A (2017) Tourism and resilience: individual, organisational and destination perspectives. Channel View Publications, Blue Ridge Summit

Hall CM, Scott D, Gössling S (2020) Pandemics, transformations and tourism: be careful what you wish for. Tour Geogr. https://doi.org/10.1080/14616688.2020.1759131

Harris T (2016) How technology Hijacks People's minds-From a magician and google design ethicist. https://medium.com/thrive-global/how-technology-hijacks-peoples-minds-from-a-magician-andgoogle-s-design-ethicist-56d62ef5edf3. Accessed 21 May 2020

Hevner AR, March ST, Park J, Ram S (2004) Design science in information systems research. MIS Q 28(1):75-105

Higgins-Desbiolles F (2020) Socialising tourism for social and ecological justice after COVID-19. Tour Geogr. https://doi.org/10.1080/14616688.2020.1757748

Higgins-Desbiolles F, Carnicelli S, Krolikowski C, Wijesinghe G, Boluk K (2019) De-growing tourism: rethinking tourism. J Sustain Tour 27(12):1926-1944

Hinrichs-Krapels S, Grant J (2016) Exploring the effectiveness, efficiency and equity (3e's) of research and research impact assessment. Palgrave Commun 2(1):1-9

Illich I (1975) Tools for conviviality. Fontana, London

Illich I (1992) In the mirror of the past. Lectures and addresses 1978-1990. Marion Boyars, London

Jamal T, Budke C (2020) Tourism in a world with pandemics: local-global responsibility and action. J Tour Futures. https://doi.org/10.1108/JTF-02-2020-0014 
Kallis G (2011) Defense of De-growth. Ecol Econ 70:873-880

Kuhn Th (1962) The structure of scientific revolutions. University of Chicago Press, Chicago

Latour B (1987) Science in action: How to follow scientists and engineers through society. Harvard University Press, Cambridge

Latour B (2000) When things strike back: a possible contribution of 'science studies' to the social sciences. Br J Sociol 51(1):107-123

Law R, Leung D, Chan ICC (2019) Progression and development of information and communication technology research in hospitality and tourism. Int J Contemp Hosp Manag 32(2):511-534

Lee Y, Kozar KA, Larsen KR (2003) The technology acceptance model: past, present, and future. Commun Assoc Inf Syst 12:752-780

Lynch C (2008) Reflexivity in research on civil society: constructivist perspectives. Int Stud Rev 10(4):708-721

Mancinelli F (2020) Digital nomads: freedom, responsibility and the neoliberal order. Inf Technol Tour. https://doi.org/10.1007/s40558-020-00174-2

Meo SA, Al Masri AA, Usmani AM, Memon AN, Zaidi SZ (2013) Impact of GDP, spending on R\&D, number of universities and scientific journals on research publications among Asian countries. PLoS ONE $8(6): 1-8$

Musgrave K, Belongie S, Lim SN (2020) A metric learning reality check. https://arxiv.org/ abs/2003.08505. Accessed 21 May 2020

Navío-Marco J, Ruiz-Gómez LM, Sevilla-Sevilla C (2018) Progress in information technology and tourism management: 30 years on and 20 years after the internet-Revisiting Buhalis \& Law's landmark study about eTourism. Tour Manag 69:460-470

Neidhardt J, Werthner H (2018) IT and tourism: still a hot topic, but do not forget IT. Inf Technol Tour 20(1-4):1-7

Nowlin C (2017) Understanding and undermining the growth paradigm. Dialogue 56:559-593

Ötsch W (2020) What type of crisis is this? The coronavirus crisis is a crisis of the economized society. Lecture at the topical lecture series of Cusanus Hochchule für Gesellschaftsgstaltung, 9 April 2020

Popper K (1974) Scientific reduction and the essential incompleteness of all sciences. In: Ayala FJ, Dobzhansky T (eds) Studies in the philosophy of biology. Reduction and related problems. Basingstoke, London, pp 259-284

Pourfakhimi S, Duncan T, Coetzee W (2018) A synthesis of technology acceptance research in tourism \& hospitality. Information and communication technologies in tourism 2018. Springer, Cham, pp $143-155$

Pritchard A (2018) Predicting the next decade of tourism gender research. Tour Manag Perspect $25: 144-146$

Putnam H (2004) The collapse of the fact/value dichotomy. Harvard University Press, Cambridge

Rendall T (2015) Goethe's Faust and Heidegger's critique of technology. Interdiscip Stud Lit Environ 22(1):115-131

Saarinen J (2018) Beyond growth thinking: the need to revisit sustainable development in tourism. Tour Geogr 20(2):337-340

Samerski S (2018) Tools for degrowth? Ivan Illich's critique of technology revisited. J Clean Prod 197:1637-1646

Sassen S (2002) Towards a sociology of information technology. Curr Sociol 50(3):365-388

Shen Y, Morrison AM, Wu B, Park J, Li C, Li M (2018) Where in the world? A geographic analysis of a decade of research in tourism, hospitality, and leisure journals. J Hosp Tour Res 42(2):171-200

Sönmez SF, Apostolopoulos Y, Tarlow P (1999) Tourism in crisis: managing the effects of terrorism. J Travel Res 38(1):13-18

Touray, S. (2020). Tracing the etourism discipline: Bibliometric analysis on the collaborative structure of the etourism research community. In: Maurer C, Siller HJ (eds.) ISCONTOUR 2020 tourism research perspectives: proceedings of the international student conference in tourism research. Norderstedt, Germany: books on demand, pp 243-257

Tufekci Z (2014) Engineering the public: Big data, surveillance and computational politics. First Monday. https://doi.org/10.5210/fm.v19i7.4901

UNWTO (2020) UNWTO World Tourism Barometer, vol 18(2). UNWTO, Madrid

Wang D, Fesenmaier DR, Werthner H, Wöber K (2010) The journal of information technology \& tourism: a content analysis of the past 10 years. Inf Technol Tour 12(1):3-16

Werthner H, Alzua-Sorzabal A, Cantoni L, Dickinger A, Gretzel U, Jannach D et al (2015) Future research issues in IT and tourism. Inf Technol Tour 15(1):1-15 
Werthner H, Klein S (1999) Information technology and tourism: a challenging relationship. Springer, Vienna

Widmer PS, Schippers MC, West MA (2009) Recent developments in reflexivity research: a review. Psychol Everyday Act 2(2):2-11

World Health Organization (WHO) (2020) Coronavirus disease 2019 (COVID-19): situation report, 57. https://www.who.int/emergencies/diseases/novel-coronavirus-2019/situation-reports. Accessed 21 May 2020

Xiang Z (2018) From digitization to the age of acceleration: on information technology and tourism. Tour Manag Perspect 25:147-150

Xiang Z, Fesenmaier DR (2017) Big data analytics, tourism design and smart tourism. Analytics in smart tourism design. Springer, Cham, pp 299-307

Xiang Z, Fuchs M, Gretzel U, Höpken W (2021) Handbook of e-Tourism. Springer International Publishing, Cham

Yuan Y, Tseng YH, Ho CI (2019) Tourism information technology research trends: 1990-2016. Tour Rev 74(1):5-19

Publisher's Note Springer Nature remains neutral with regard to jurisdictional claims in published maps and institutional affiliations.

\section{Affiliations}

\section{Ulrike Gretzel $^{1}$ D Matthias Fuchs ${ }^{2} \cdot$ Rodolfo Baggio $^{3,4}$ - Wolfram Hoepken ${ }^{5}$. Rob Law ${ }^{6} \cdot$ Julia Neidhardt $^{7}$. Juho Pesonen ${ }^{8} \cdot$ Markus Zanker $^{9} \cdot$ Zheng Xiang $^{10}$}

Matthias Fuchs

matthias.fuchs@miun.se

Rodolfo Baggio

rodolfo.baggio@unibocconi.it

Wolfram Hoepken

wolfram.hoepken@rwu.de

Rob Law

rob.law@polyu.edu.hk

Julia Neidhardt

julia.neidhardt@tuwien.ac.at

Juho Pesonen

juho.pesonen@uef.fi

Markus Zanker

markus.zanker@unibz.it

Zheng Xiang

philxz@vt.edu

1 USC Center for Public Relations, Annenberg School for Communication and Journalism, University of Southern California, 3502 Watt Way, Los Angeles, CA 90089, USA

2 Department of Economics, Geography, Law and Tourism, Mid-Sweden University, Östersund, Sweden

3 Bocconi University, via Röntgen, 1, 20136 Milan, Italy

4 National Research Tomsk Polytechnic University, 30 Lenin Avenue, Tomsk 634050, Russia

5 Institute for Digital Transformation, Ravensburg-Weingarten University, Doggenriedstr, 88250 Weingarten, Germany 
6 School of Hotel and Tourism Management, The Hong Kong Polytechnic University, 17 Science Museum Road, TST East, Kowloon, Hong Kong

7 Faculty of Informatics, Vienna University of Technology, Favoritenstraße 9-11, HC0204A-1040 Wien, Austria

8 Business School, University of Eastern Finland, Yliopistonkatu 2, 80100 Joensuu, Finland

9 Faculty of Computer Science, Free University of Bozen-Bolzano, Dominikanerplatz 3, piazza Domenicani, 3, 39100 Bozen-Bolzano, Italy

10 The Howard Feiertag Department of Hospitality and Tourism Management, Virginia Tech, 295 West Campus Drive, Blacksburg, VA 24061, USA 